\title{
Resistance of Peanut to Sclerotinia Blight and the Effect of Acibenzolar-S-methyl and Fluazinam on Disease Incidence
}

\author{
A. V. Lemay, Former Research Assistant, J. E. Bailey, Professor (Deceased), and B. B. Shew, Research Assistant \\ Professor, North Carolina State University, Department of Plant Pathology, Raleigh 27695-7616
}

\begin{abstract}
Lemay, A. V., Bailey, J. E., and Shew, B. B. 2002. Resistance of peanut to Sclerotinia blight and the effect of acibenzolar-S-methyl and fluazinam on disease incidence. Plant Dis. 86:1315-1317.

Sclerotinia minor, a soilborne fungal pathogen of peanut, can cause serious yield loss in North Carolina. A field test was implemented to study genotype reaction, and the effect of acibenzolar-S-methyl (a plant activator) and the fungicide fluazinam on disease incidence. In all, 13 genotypes in 1997 and 12 genotypes in 1998 were evaluated. Three applications of acibenzolar$S$-methyl $(0.14 \mathrm{~kg}$ a.i./ha) or fluazinam $(0.58 \mathrm{~kg}$ a.i./ha) were made on a calendar-based schedule. Disease ratings were made weekly in 1997 and every other week in 1998. Fluazinam suppressed disease at all sites and increased yield at two of three locations. Acibenzolar- $S$-methyl had no effect on disease incidence or yield. The advanced breeding line N92056C and cvs. Tamrun 98 (TX 901417) and Perry (N93112C) had moderate to high levels of resistance to $S$. minor and produced high yields compared with susceptible cv. NC 7. Lines derived from wild species also demonstrated moderate to high levels of resistance relative to NC 7 and represent potential breeding lines.
\end{abstract}

Additional keywords: Arachis hypogaea, groundnut

In North Carolina, the fungus Sclerotinia minor Jagger can cause great reductions in yield of peanut (Arachis hypogaea L.) and economic loss to producers. Prior to 2000, management strategies for minimizing Sclerotinia blight in peanut included crop rotation, planting cultivars with moderate resistance, and utilizing the fungicide iprodione. Higher levels of resistance and more effective fungicides are needed for continued management of this disease.

In the North Carolina and Virginia production region, Virginia-type peanut is planted. This is a commercial designation based on seed size. Virginia-type peanut has larger seeds and greater than $40 \%$ fancy pods, whereas the runner-type peanut has smaller seeds and less than $40 \%$ fancy pods. A Virginia-type peanut fully resistant to $S$. minor currently is not available.

Iprodione, a dicarboximide fungicide, was registered in 1986 and provides moderate suppression of Sclerotinia blight of peanut. Resistance to iprodione and other dicarboximides has been shown in several fungal pathogens, including isolates of $S$.

Corresponding author: A. V. Lemay

E-mail: andrea.lemay@aphis.usda.gov

Use of brand names in this publication does not imply endorsement of the products named or criticism of similar ones not mentioned.

Accepted for publication 9 July 2002.

Publication no. D-2002-1015-04R

(C) 2002 The American Phytopathological Society minor $(2,12,13,18,20)$. Further testing showed that these $S$. minor isolates were cross-resistant to dicloran and pentachloronitrobenzene, but not fluazinam (19). Fluazinam, a protectant fungicide, previously has been studied for its suppression of $S$. minor $(8,9,18,19)$.

Acibenzolar- $S$-methyl is a systemic inducer of a resistance response in plants, but has no direct activity against pathogens (14). This compound has been effective in control of several fungal pathogens but, to our knowledge, never has been evaluated for control of Sclerotinia blight of peanut.

The objectives of this study were to analyze the efficacy of fluazinam and acibenzolar-S-methyl on managing Sclerotinia blight and to evaluate peanut genotypes for resistance to $S$. minor.

\section{MATERIALS AND METHODS}

Thirteen peanut genotypes were planted on 19 May 1997 at a site with a history of Sclerotinia blight disease in Gates County, NC (site 1). In 1998, 12 genotypes were planted at two locations in Gates County, $\mathrm{NC}$ on 21 (site 3) and 29 May (site 2). The cultivars NC 7, VA 93B (Virginia-type commercial cultivars), and Tamspan 90 (Spanish-type commercial cultivar) served as susceptible, moderately resistant, and resistant comparisons, respectively. The advanced breeding lines N92056C, N93107C, and N91026E were studied along with the recently released cv. Perry (N93112C) (T. Isleib, unpublished data). These are Virginia-type breeding lines developed at North Carolina State Univer- sity (NCSU) (T. Isleib, personal communication). The breeding line NC 3033, although having unfavorable agronomic characteristics and not meeting market criteria, was included in this study to provide an additional comparison for resistance levels. This line has moderate to high levels of resistance. Five lines derived from crosses with wild Arachis spp. at NCSU were included (T. Stalker, personal communication). The breeding line Tamrun 98 (runner market-type peanut typically not grown in North Carolina and Virginia) was included in 1998. All sites were cropped to cotton during the previous season. The experimental design was a randomized complete block with three replications in 1997 and four replications in 1998. Peanut plants were seeded $15 \mathrm{~cm}$ apart in plots consisting of two $15-\mathrm{m}$ rows, spaced $0.9 \mathrm{~m}$ apart. Four border rows planted with NC 7 separated each plot. Fields were not irrigated. Standard cultural practices were followed.

Applications of fluazinam $(0.58 \mathrm{~kg}$ a.i./ha, Omega 500F; Syngenta Crop Protection, Greensboro, NC) and acibenzolar$S$-methyl (0.14 kg a.i./ha, Actigard 50WG; Syngenta Crop Protection) were made using a tractor-mounted sprayer (three hollow cone nozzles/row, $276 \mathrm{kPa}$, water at 142 liters/ha). The first application was based on plant growth; specifically, when limbs within a row began to touch. Subsequent applications were made at 21-day intervals; however, in 1998, excessively wet conditions prevented field access for the second scheduled application. Thus, applications were made on 7 and $29 \mathrm{Au}$ gust and 19 September 1997; on 6 August and 10 and 29 September 1998 at site 2; and 7 August and 3 and 25 September 1998 at site 3 .

Disease ratings, initiated in August, were made by counting row increments of $30 \mathrm{~cm}$ showing signs of $S$. minor (white mycelia on stems and pegs) or symptoms of Sclerotinia blight (light-tan lesions on stems). Ratings were made weekly in 1997 and every other week in 1998. Plants were dug on 2 November and harvested using a combine on 5 November 1997. In 1998, plants were dug on 30 October and 4 November, and harvested 2 and 6 November at sites 1 and 2, respectively.

Areas under the disease progress curves (AUDPC) were calculated according to the method used by Shaner and Finney (17). An analysis of variance of AUDPC (square 
root transformed) and yield data was conducted (significance level of $P=0.05$ ). Means were separated with Waller-Duncan $k$-ratio $(=100) t$ tests, which approximate to a significance level of $P=0.05$ (SAS Institute, Cary, NC).

\section{RESULTS}

Main effects of genotype and chemical treatment on AUDPC were significant at all experiment sites (Tables 1 and 2). There were no interaction effects. In both years, warm and dry conditions delayed plant growth and disease onset. In 1997, the first symptoms of Sclerotinia blight appeared in early August and disease progressed slowly for the remainder of the season. In 1998, plants remained small until August, and disease symptoms did not appear until mid- to late September. In 1998, disease pressure was low compared with 1997 and site 2 had lower disease pressure than site 3 (not evaluated statistically).

Cvs. NC 7, VA 93B, and Tamspan 90 are susceptible, moderately resistant, and resistant, respectively, to $S$. minor. NC 7 had the most disease at all sites (Table 1). Moderately resistant VA 93B had consistently lower disease than NC 7, although this was not significant at site 2. Tamspan
90 had lower disease than NC 7 and VA 93B at all sites. NC 3033 consistently had less disease than the moderately resistant VA 93B, but had more disease than resistant Tamspan 90.

Of the wild species-derived lines, 96RL19, 96RL20, and 96RL22 had disease levels equivalent to VA 93B at two of three sites, and at one site was equivalent to Tamspan 90. Lines 96RL18 and 96RL21 consistently had less disease than the other wild-derived lines. 96RL18 had disease levels equivalent to Tamspan 90 at all sites. 96RL21 had less disease than the moderately resistant VA 93B at two sites and had disease levels equivalent to Tamspan 90 at one site.

The advanced breeding line N92056C had lower disease than VA 93B at two of the three sites and disease reaction similar to Tamspan 90 at one site. Its disease reaction was similar to NC 3033, a line with resistance between VA 93B and Tamspan 90. Cv. Perry demonstrated moderate resistance at all sites. Tamrun 98 had less disease than VA 93B but had more disease than Tamspan 90 (only tested in 1 year). The advanced breeding lines N93107C and N91026E had disease levels similar to $\mathrm{NC} 7$ and were dropped from the experiments in 1998.

Table 1. Effect of peanut genotype on area under the disease progress curve for Sclerotinia blight and yield in North Carolina

\begin{tabular}{|c|c|c|c|c|c|c|}
\hline & \multicolumn{2}{|c|}{ Site 1} & \multicolumn{2}{|c|}{ Site 2} & \multicolumn{2}{|c|}{ Site 3} \\
\hline & AUDPC ${ }^{w}$ & Yield (kg) & AUDPC ${ }^{w}$ & Yield (kg) & AUDPC ${ }^{w}$ & Yield (kg) \\
\hline $\mathrm{NC} 7$ & $814 \mathrm{a}$ & $3,490 \mathrm{~d}$ & $171 \mathrm{a}$ & 4,164 be & $197 \mathrm{a}$ & 4,510 be \\
\hline VA 93B & $478 \mathrm{~b}$ & $3,481 \mathrm{~d}$ & $131 \mathrm{ab}$ & $4,882 \mathrm{a}$ & 77 be & $4,321 \mathrm{c}$ \\
\hline Tamspan 90 & $123 \mathrm{de}$ & $3,363 \mathrm{~d}$ & $12 \mathrm{f}$ & $4,409 \mathrm{ab}$ & $2 \mathrm{~g}$ & $4,219 \mathrm{c}$ \\
\hline NC 3033 & $305 \mathrm{bcd}$ & 3,926 bcd & 51 cde & $3,343 \mathrm{a}$ & 17 ef & $3,230 \mathrm{de}$ \\
\hline 96RL18x & $142 \mathrm{de}$ & $4,584 \mathrm{ab}$ & $26 \mathrm{ef}$ & $3,553 \mathrm{~d}$ & $11 \mathrm{fg}$ & $3,553 \mathrm{de}$ \\
\hline 96RL19x & $159 \mathrm{de}$ & $3,788 \mathrm{~cd}$ & 84 be & $4,265 \mathrm{abc}$ & $54 \mathrm{~cd}$ & $3,420 \mathrm{de}$ \\
\hline 96RL20 $0^{x}$ & $206 \mathrm{de}$ & $3,888 \mathrm{bcd}$ & 82 be & 4,177 be & $55 \mathrm{~cd}$ & 3,487 de \\
\hline 96RL2 $1^{x}$ & $100 \mathrm{e}$ & $3,174 \mathrm{~d}$ & $58 \mathrm{cde}$ & $3,302 \mathrm{e}$ & $45 \mathrm{~cd}$ & $2,779 \mathrm{f}$ \\
\hline 96RL22x & $282 \mathrm{cde}$ & $4,539 \mathrm{abc}$ & 89 be & $4,076 \mathrm{bcd}$ & $59 \mathrm{~cd}$ & 3,002 ef \\
\hline N92056C & $188 \mathrm{de}$ & $4,984 \mathrm{a}$ & $71 \mathrm{~cd}$ & 4,211 be & $45 \mathrm{~cd}$ & $4,962 \mathrm{a}$ \\
\hline Perry $^{z}$ & $444 \mathrm{~b}$ & $4,313 \mathrm{abc}$ & $134 \mathrm{ab}$ & $4,604 \mathrm{ab}$ & 96 be & $4,721 \mathrm{ab}$ \\
\hline Tamrun $98^{z}$ & $\ldots$ & $\ldots$ & 39 de & 3,770 cde & $33 \mathrm{de}$ & $4,246 \mathrm{c}$ \\
\hline N93107C & $667 \mathrm{a}$ & $4,811 \mathrm{ab}$ & $\ldots$ & $\ldots$ & $\ldots$ & $\ldots$ \\
\hline $\mathrm{N} 91026 \mathrm{E}^{\mathrm{y}}$ & $694 \mathrm{a}$ & $4,322 \mathrm{abc}$ & $\ldots$ & $\ldots$ & $\ldots$ & $\ldots$ \\
\hline
\end{tabular}

${ }^{\mathrm{w}}$ Area under the disease progress curve (AUDPC) averaged across compound treatments. Sites 2 and

3 values square-root transformed prior to analysis, but are back-transformed for presentation pur-

poses. The susceptible cultivar NC 7, moderately resistant cultivar VA 93B, and resistant cultivar

Tamspan 90 served as checks. Genotypes with the same letter are not significantly different according to the Waller-Duncan $k$-ratio $t$ test, $k=100$.

${ }^{x}$ Wild-derived germplasm lines GP-NC WS11 through GP-NC WS15.

${ }^{y}$ Advanced breeding lines.

${ }^{\text {z }}$ Perry (N93112C); Tamrun 98 (TX 901417).

Table 2. Effect of acibenzolar-S-methyl and fluazinam on area under the curve for Sclerotinia blight in peanut and yield $(\mathrm{kg} / \mathrm{ha})^{\mathrm{z}}$

\begin{tabular}{lccccccc}
\hline & \multicolumn{2}{c}{ Site 1 } & & \multicolumn{2}{c}{ Site 2 } & & \multicolumn{2}{c}{ Site 3 } \\
\cline { 2 - 3 } \cline { 7 - 8 } \cline { 7 - 8 } Compound & AUDPC & Yield (kg) & & AUDPC & & AUDPC & Yield (kg) \\
\hline Fluazinam & $295 \mathrm{~b}$ & $4,503 \mathrm{a}$ & & $64 \mathrm{~b}$ & & $16 \mathrm{~b}$ & $4,051 \mathrm{a}$ \\
Acibenzolar-s-methyl & $413 \mathrm{a}$ & $3,798 \mathrm{~b}$ & & $81 \mathrm{a}$ & & $81 \mathrm{a}$ & \\
Control & $354 \mathrm{ab}$ & $3,790 \mathrm{~b}$ & & $100 \mathrm{a}$ & & $64 \mathrm{a}$ & $3,742 \mathrm{~b}$ \\
\hline
\end{tabular}

${ }^{\mathrm{z}}$ Sites 2 and 3 area under the disease progress curve (AUDPC) were square-root transformed prior to analysis, but are back-transformed for presentation purposes. Means are averaged across genotypes. Yield data for site 2 were omitted because compound effects were not significant. Values with the same letter are not significantly different according to the Waller-Duncan $k$-ratio test, $k=100$.

The three checks, NC7, VA 93B, and Tamspan 90, had similar yields at sites 1 and 3, and VA 93B had a higher yield than NC 7 at site 2 (Table 1). At site 1, which had the highest disease pressure, 96RL18 and 96RL22 and the advanced breeding lines N92056C, N91026E, and N93107C had significantly higher yields than the checks. At sites 2 and 3, where disease pressure was low, the check cultivars had yields consistently better than NC 3033, 96RL18, and 96RL21. At site 2, no breeding lines yielded better than the checks. At site 3, only N92056C yielded higher than the checks, while Perry yielded higher than VA 93B and Tamspan 90. All of the wildderived species had lower yields than the checks.

Fluazinam significantly reduced the AUDPC at sites 2 and 3 compared with the nontreated control and in all three tests compared with acibenzolar- $S$-methyl (Table 2). There were no significant differences between the acibenzolar- $S$-methyl treatments and the nontreated control in all experiments.

Fluazinam treatments increased yield at sites 1 and 3 compared with the nontreated control and acibenzolar- $S$-methyl treatments. Acibenzolar-S-methyl treatments did not differ from the untreated controls. There was no significant treatment effect on yield at site 2 .

\section{DISCUSSION}

Plant canopy size and row closure influence soil and canopy temperature and moisture, directly affecting development of Sclerotinia blight $(3,11,15)$. In 1997 and 1998, plant growth was suppressed until mid-August due to hot and dry weather, which decreased soil moisture levels and reduced the shaded area around the plant. During disease-favorable years, when soil temperatures are cool and moisture levels are high, symptoms can first appear in mid-July in fields with a history of Sclerotinia blight (J. E. Bailey, unpublished). In these studies, symptoms in the field were on the increase in mid-August in 1997, but the first symptoms were not observed until mid- to late September in 1998.

Three sprays were made at each site on a calendar basis; however, during some of these spray intervals, weather conditions were not conducive for disease development. Overall, more sprays were applied than needed. Growers begin fungicide treatments for Sclerotinia blight in midJuly and can apply up to three sprays per season. The low disease pressure in 1998 was probably due to unfavorable environmental conditions. Therefore, routine scouting for disease development, using disease advisories if available (16), and maintenance of concise records of field history help determine when sprays are needed.

Acibenzolar- $S$-methyl had no discernable activity on the disease Sclerotinia 
blight or yield. A previous study showed that acibenzolar-S-methyl significantly reduced disease caused by $S$. sclerotiorum on field-grown soybeans (10). S. minor and $S$. sclerotiorum share many of the same infection mechanisms. One major difference is that ascospores of S. sclerotiorum play an important role in the disease cycle on some hosts, but do not for S. minor on peanut. The infection process and host plant may influence acibenzolar- $S$-methyl activity in this pathosystem.

The disease rating method used in our study did not allow a measure of disease that correlates well with yield. The method used provided information on the increments of disease progress, but not the actual number of diseased limbs and lesion lengths. Also, chemical activity at the soil interface and belowground, where the pegs and pods form, was not measured. Yields also may vary depending on the yield potential and resistance of a genotype.

The advanced breeding line N92056C shows promise as a potential candidate for release as an $S$. minor-resistant cultivar. This line was initially bred for Cylindrocladium parasiticum resistance, but also showed resistance to $S$. minor in $C$. parasiticum screening trials. In this study, N92056C was resistant to $S$. minor in both years and was high yielding. This line has been entered into the breeder seed increase program, but its possible release to growers is unknown (T. Isleib, unpublished data). $\mathrm{Cv}$. Perry was moderately resistant to $S$. minor at two of three sites in this study and in initial field screenings. It is moderately resistant to $C$. parasiticum and Cercospora arachidicola, the causal organism of early leaf spot (T. Isleib, unpublished data). Both N92056C and Perry are Virginia-type peanut cultivars that fit the market criteria in North Carolina and Virginia.

Cv. Tamrun 98 exhibited high resistance to $S$. minor and intermediate yields when compared with NC 7 in 1 year of testing. Damicone et al. (9) also found that Tamrun 98 had high resistance to $S$. minor when compared with Okrun, Tamrun 96, and Georgia Green, and had intermediate yields. This cultivar may not be used extensively in the Virginia-Carolina region due to its small seed size, which does not meet traditional market criteria.

The breeding lines N93107C and N91026E were susceptible to $S$. minor. This supports previous findings in which these genotypes performed similar to the susceptible cultivar NC 7 (T. Isleib, unpublished data). Both lines have low levels of resistance to Cylindrocladium parasiticum. Although susceptible to $S$. minor, both lines produced high yields, which may be due to their high-yielding potential or tolerance to $S$. minor. These lines may be released, but contain unfavorable charac- teristics that will prevent their widespread use in North Carolina and Virginia. These two lines were not evaluated in 1998.

Lines 96RL18 through 96RL22 (GP-NC WS11 through GP-NC WS15) demonstrated moderate to high resistance to $S$. minor. These lines have resistance to $\mathrm{Cer}$ cospora arachidicola or Cercosporidium personatum, the causal agents of early and late leaf spot, respectively (21). These germplasm lines are derived from interspecific crosses with Arachis cardenasii and will not be released as cultivars due to poor agronomic characteristics inherited from the wild genotype. Further breeding with these selections may result in cultivars with resistance to both $S$. minor and C. arachidicola, which would be valuable to growers.

Morphological characteristics of the genotypes in this study may contribute to the observed disease reactions. Cvs. Tamspan 90 and VA 93B both have open and upright canopies, resulting in increased air movement within the canopy and decreased limb-to-soil surface contact. Fungicides have been shown to perform more effectively against $S$. minor on cultivars with open canopies $(4,7)$. Cv. NC 7 has a recumbent growth habit with more limb-tosoil surface contact, which increases potential infection sites $(3,5)$. The advanced breeding lines and wild species-derived lines that exhibited moderate to high resistance may have a canopy architecture $(1,6)$ that reduces disease potential.

Sclerotinia blight has been a problem in North Carolina for about 20 years; however, management strategies are limited. The findings in this study could impact management strategies for Sclerotinia blight as well as Cylindrocladium black rot through the evaluation of peanut lines (several of which contain a certain level of resistance to Cylindrocladium parasiticum) for resistance to $S$. minor and testing chemistries for Sclerotinia blight suppression.

\section{ACKNOWLEDGMENTS}

We thank V. Curtis for research assistance, the North Carolina Peanut Growers Association for funding the research, and T. Isleib and T. Stalker for providing the genotypes studied in this research.

\section{LITERATURE CITED}

1. Bailey, J. E., and Brune, P. D. 1997. Effect of crop pruning on Sclerotinia blight of peanut. Plant Dis. 81:990-995.

2. Brenneman, T. B., Phipps, P. M., and Stipes, R. J. 1987. Control of Sclerotinia blight of peanut: Sensitivity and resistance of Sclerotinia minor to vinclozolin, iprodione, dicloran, and PCNB. Plant Dis. 71:87-90.

3. Brune, P. D., and Bailey, J. E. 1992. Modification of canopy microclimate by pruning to control Sclerotinia blight of peanut. (Abstr.) Proc. Am. Peanut Res. Educ. Soc. 24:42.

4. Butzler, T. M., Bailey, J. E., and Beute, M. K. 1998. Integrated management of Sclerotinia blight in peanut: Utilizing canopy morphol- ogy, mechanical pruning, and fungicide timing. Plant Dis. 82:1312-1318.

5. Chappell, G. F., II. 1992. Evaluation of mechanisms of resistance to Sclerotinia minor in peanut genotypes. M.S. thesis, North Carolina State University, Raleigh.

6. Coffelt, T. A., and Porter, D. M. 1982. Screening peanuts for resistance to Sclerotinia blight. Plant Dis. 66:385-387.

7. Coyne, D. P., Stedman, J. R., and Anderson, F. N. 1974. Effect of modified architecture of great northern dry bean varieties (Phaseolus vulgaris) on white mold severity and components of yield. Plant Dis. Rep. 58:379-382.

8. Damicone, J. P., and Jackson, K. E. 1996. Disease and yield responses to fungicides among peanut cultivars differing in reaction to Sclerotinia blight. Peanut Sci. 23:81-85.

9. Damicone, J. P., Melouk, H. A., and Jackson, K. E. 1997. Reaction of runner cultivars and breeding lines of peanut to Sclerotinia blight and their responses to fungicide treatment. (Abstr.) Proc. Am. Peanut Res. Educ. Soc. 30:24.

10. Dann, E., Diers, B., Byrum, J., and Hammerschmidt, R. 1998. Effect of treating soybean with 2,6-dichloroisonicotinic acid (INA) and benzothiadiazole (BTH) on seed yields and the level of disease caused by Sclerotinia sclerotiorum in field and greenhouse studies. Eur. J. Plant Pathol. 104:271-278.

11. Dow, R. L., Porter, D. M., and Powell, N. L. 1988. Effect of environmental factors on Sclerotinia minor and Sclerotinia blight of peanut. Phytopathology 78:672-676.

12. Gouot, J. M. 1988. Characteristics and population dynamics of Botrytis cinerea and other pathogens resistant to dicarboximides. Pgs. 53-55. in: Fungicide Resistance in North America. C. J. Delp, ed. American Phytopathological Society, St. Paul, MN.

13. Hubbard, J. C., Subbarao, K. V., and Koike, S. T. 1997. Development and significance of dicarboximide resistance in Sclerotinia minor isolates from commercial lettuce fields in California. Plant Dis. 81:148-153.

14. Kessman, H., Staub, T., Ligon, J., Oostendorp, M., and Ryals, J. 1994. Activation of systemic acquired disease resistance in plants. Eur. J. Plant Pathol. 100:359-369.

15. Phipps, P. M. 1995. An assessment of environmental conditions preceding outbreaks of Sclerotinia blight of peanut in Virginia. Peanut Sci. 22:90-93.

16. Phipps, P. M., Deck, S. H., and Walker D. R. 1997. Weather-based crop and disease advisories for peanuts in Virginia. Plant Dis. 81:236244.

17. Shaner, G., and Finney, R. E. 1977. The effect of nitrogen fertilization on the expression of slow-mildewing resistance in Knox wheat. Phytopathology 67:1051-1056.

18. Smith, F. D., Phipps, P. M., and Stipes, R. J. 1991. Agar plate, soil plate, and field evaluations of fluazinam and other fungicides for control of Sclerotinia minor on peanut. Plant Dis. 75:1138-1143.

19. Smith, F. D., Phipps, P. M., and Stipes, R. J. 1992. Fluazinam: A new fungicide for control of Sclerotinia blight and other soil borne pathogens of peanut. Peanut Sci. 19:115-120.

20. Smith, F. D. T., Phipps, P. M., Stipes, R. J., and Brenneman, T. B. 1995. Significance of insensitivity of Sclerotinia minor to iprodione in control of Sclerotinia blight of peanut. Plant Dis. 79:517-523.

21. Stalker, H. T., Beute, M. K., Shew, B. B., and Isleib, T. G. 2002. Registration of five leaf spot-resistant peanut germplasm lines. Crop Sci. 42:314-316. 